\title{
KOMUNIKASI ANTARPRIBADI PETUGAS LEMBAGA PEMASYARAKATAN DALAM MEMBINA NARAPIDANA NARKOBA
}

\author{
Maini Sartika ${ }^{1}$, Mita Fitrati2 ${ }^{*}$, Nur Anisah ${ }^{3}$, dan Nadia Muharman ${ }^{4}$ \\ ${ }^{1,2,3,4}$ Universitas Syiah Kuala, Banda Aceh \\ "khieuf@gmail.com
}

\begin{abstract}
This research was conducted to find out the interpersonal communication of Banda Aceh Class IIA Prison Officers in Fostering Drug Prisoners and what are the supporting factors and inhibiting factors. The method used is the Qualitative Method, which is researching in depth with data collection techniques such as observation, interviews and documentation. This research used Social Penetration theory, a process of relationship with others, where there are various adaptation processes between the two. The results of his research, the implementation of fostering prisoners with interpersonal communication approach in Class IIA Penitentiary Banda Aceh has been running as it should because the training carried out has followed existing procedures, although there are things that occur in prisons such as prisoners' indiscipline then that can be resolved with wise. Interpersonal communication in the coaching process that is carried out is also very appropriate, because a good coaching is also good communication. In conducting a coaching program, Banda Aceh Class IIA Prison certainly has supporting factors in the form of an adequate budget and the enthusiastic participation of fostered citizens in participating in coaching activities. There are also inhibiting factors, namely the lack of discipline from prisoners in carrying out training programs and the lack of prison staff.
\end{abstract}

Keywords: Interpersonal Communication, Penitentiary, Prisoners

\begin{abstract}
Abstrak
Penelitian ini dilakukan untuk mengetahui Komunikasi Antarpribadi Petugas Lapas Kelas IIA Banda Aceh Dalam Membina Narapidana Narkoba serta apa saja faktor pendukung dan faktor penghambatnya. Metode yang digunakan adalah Metode Kualitatif, yaitu meneliti secara mendalam dengan teknik pengumpulan data seperti observasi dan wawancara. Penelitian ini menggunakan teori penetrasi sosial merupakan suatu proses hubungan dengan orang lain, terjadi berbagai proses adaptasi di antara keduanya. Hasil penelitiannya, pelaksanaannya sudah berjalan sebagaimana mestinya karena pembinaan yang dilakukan sudah mengikuti prosedur yang ada, meskipun ada hal-hal yang terjadi di dalam Lapas seperti ketidaksiplinan narapidana maka hal itu dapat diselesaikan dengan bijak. Komunikasi antarpribadi dalam proses pembinaan yang dijalankanpun sudah sangat tepat, karena suatu pembinaan yang baik adanya komunikasi yang baik pula. Dalam melakukan program pembinaan tentunya Lapas Kelas IIA Banda Aceh memiliki faktor pendukung berupa anggaran yang memadai dan partisipasi antusias warga binaan dalam mengikuti kegiatan pembinaan. Ada juga faktor penghambatnya yaitu kurangnya kedisiplinan dari narapidana dalam menjalankan program pembinaan dan kurangnya tenaga kerja petugas lapas.
\end{abstract}

Kata Kunci: Komunikasi Antarpribadi , Lembaga Pemasyarakatan, Narapidana

\section{PENDAHULUAN}

113 narapidana kabur dari lembaga permasyarakatan II A Banda Aceh pada 29 november 2018. Menurut Agus, Kepala Kantor Wilayah Kementerian Hukum dan HAM Aceh hasil investigasi kaburnya 
ratusan napi murni keinginan para napi. "Naluri orang tidak ingin dihukum, mereka tidak ingin berada di dalam. Sehingga saat ada kesempatan dan kelengahan pegawai, dimanfaatkan oleh mereka." urainya. Dia menjelaskan, narapida yang kabur rata-rata tersandung kasus narkoba (Kompas.com, 2018). Menurut Kapolresta Banda Aceh Kombes T Saladin, polisi menemukan 183 bungkus kecil berisi dan ganja dan satu penghisap sabu dibelakangn kamar narapidana saat pengecekan (Warta Ekonomi.co.id, 2018) Ini membuktikan bahwa tidak hanya diluar penjara, para napi yang masih dalam pembinaan di LP pun masih menyalagunakan narkoba.

Narkoba merupakan singkatan dari narkotika dan obat/bahan yang berbahaya. Selain narkoba, istilah lain yang di perkenalkan khususnya oleh Departemen Kesehatan Republlik Indonesia adalah NAPZA yang merupakan singkatan dari Narkotika, Alkohol, Psikotropika dan Zat adiktif. Semua istilah ini, baik narkoba atau napza, mengacu pada sekelompok zat yang umumnya mempunyai resiko kecanduan bagi penggunanya.

Bahaya penyalahgunaan tidak hanya terbatas pada diri pecandu, melainkan dapat membawa akibat lebih jauh lagi, yaitu gangguan terhadap tata kehidupan masyarakat yang bisa berdampak pada malapetaka runtuhnya suatu bangsa negara dan dunia. Negara yang tidak dapat menanggulangi penyalahgunaan dan peredaran gelap narkotika akan diklaim sebagai sarang kejahatan. Hal tersebut akan menimbulkan dampak negatif bagi citra suatu bangsa.

Salah satu tindakan negara dalam menanggulangan penyalagunaan narkoba adalah dengan melakukan pembinaan para napi di dalam lembaga permasyarakatan. Pembinaan yaitu proses, perbuatan, cara membina, pembaharuan, penyempurnaan, usaha tindakan dan kegiatan yang dilakukan secara berdaya dan berhasil guna untuk memperoleh hasil yang lebih baik.

Pembinaan di LAPAS (Lembaga Pemasyarakatan) berupa bimbingan. Menurut Ketentuan Keputusan Menteri Kehakiman Nomor : M.02- PK.04.10 Tahun 1990 Tentang Pola Pembinaan Narapidana/Tahanan, pembinaan adalah; "Pembinaan meliputi tahanan, pelayanan tahanan, sistem pembinaan narapidana dan bimbingan klien." (www. bimkemasditjenpas.file.com Diakses pada 4 Februari 2019 pukul 21.00 WIB Pembinaan yang dimaksud dalam pembahasan ini adalah merupakan suatu pembinaan kepribadian pemakai narkoba/warga binaan untuk bisa mandiri, dapat bertanggung jawab, dan dapat menyelesaikan permasalahan- permasalahan yang mereka hadapi. Pembinaan ini juga merupakan salah satu proses yang dilakukan untuk merubah tingkah laku individu kepada yang lebih baik serta membentuk kepribadian dan berakhlak mulia sehingga apa yang dicita-citakan dapat tercapai sesuai yang diharapkan.Dalam melakukan pembinaan tentu saja dilakukan komunikasi Jenis komunikasi tersebut diangap paling efektif untuk mengubah sikap, pedapat, atau perilaku manusia berhubung prosesnya yang dialogis (Liliweri,1997). Komunikasi antarpribadi akan menunjukkan keefektifannya ketika komunikator dan komunikan sudah saling terbuka. Dan untuk mengukur efektivitas komunikasi antarpribadi, dibutuhkan lima indikator yang dipaparkan oleh DeVito dalam (Liliweri,1997:13) yaitu keterbukaan (Openess), empati (Emphaty), dukungan (Supportiveness), rasa positif (Possitiveness), dan kesamaan (Equality).

Teori yang digunakan dalam penelitian ini adalah teori penetrasi sosial. Teori ini digunakan sebagai teori acuan karena dalam teori penetrasi sosial sesuai dengan fenomena yang terdapat dalam latar belakang masalah, yakni mengenai 
pembinaan narapidana melalui pendekatan komunikasi antarpribadi antara petugas lapas dengan narapidana.

Dalam teori ini diibaratkan seperti lapisan kulit bawang, ada lapisan luar sampai lapisan terdalam. Lapisan pertama adalah orientasi yaitu perkenalan, lapisan kedua adalah penjajakan afektif yaitu munculnya diri, lapisan ketiga adalah pertukaran afektif yaitu adanya komitmen dan kenyamanan dan lapisan keempat adalah pertukaran stabil yaitu kejujuran total. Ini suatu hal yang dapat dijalankan dalam proses pembinaan narapidana, dimana ada tahapan-tahapan proses dalam melakukan suatu pembinaan yang baik. Maka dari itu teori ini sangat tepat digunakan dalam penelitian ini.

Salah satu usaha untuk meningkatkan human relations seseorang adalah dengan meningkatkan hubungan dengan orang lain secara berkesinambungan. Meningkatkan hubungan seseorang dapat dilihat dengan mengetahui bagaimana suatu hubungan interpersonal berkembang (relationship development), hal ini dapat dilakukan dengan mempelajari sebuah teori komunikasi yang disebut Teori Penetrasi Sosial (Social Penetrasi Theory: selanjutnya di tulis SPT) (Altman, I., \& Taylor, 1973)

Proses penetrasi sosial menurut Altman \& Taylor (dalam West, et.al., (2013:205209) dijelaskan dalam tahap-tahap sebagai berikut: Tahap Orientasi (Orientation Stage). Dalam tahap ini hanya sedikit mengenai diri kita yang terbuka untuk orang lain, hanya sebatas apa yang bisa kita perlihatkan kepada orang lain bersifat pertanyaan umum seperti nama, alamat, umur, asal daerah, pekerjaan, dan lain sebagainya. Dalam tahapan ini pembicaraan yang terjadi mengalir apa adanya dan bisaanya orang cenderung bertindak sopan, tidak mengevaluasi atau mengkritik pada tahapan orientasi.

Pada tahap pertukaran penjajakan afektif merupakan perluasan area publik dari diri dan terjadi ketika aspek- aspek dari kepribadian asli seorang individu mulai muncul, apa yang tadinya privat menjadi publik. Rasa berhati-hati sudah mulai berkurang, hubungan pada tahap ini umumnya lebih ramah dan santai, dan jalan menuju tahap berikutnya yang bersifat akrab dimulai.

Pada tahap pertukaran afektif terdapat penekanan pada komitmen dan kenyamanan.Tahap ini ditandai oleh persahabatan yang dekat dan pasangan yang intim dan termasuk pola interaksi yang lebih santai, tanpa beban, dan terjadi secara spontan. Terkadang ditahap ini muncul adanya ketidaksetujuan, ketidakramahan, maupun kesalahpahaman, akan tetapi hal ini bukan suatu ancaman bagi hubungan secara keseluruhan.

Pada tahap pertukaran stabil kejujuran total dan keintiman. Pada tahap ini, sifatnya sudah dapat memprediksikan tindakantindakan dan respon diantara mereka masing- masing dengan baik. Informasi yang dibicarakan sudah sangat dalam dan menjadi inti dari pribadi masing-masing. Misalnya soal nilai, konsep diri, atau perasaan emosi terdalam.

Komunikasi yang akan diteliti pada penelitian ini adalah untuk melihat bagaimana komunikasi antarpribadi antara petugas lapas dan narapidana melalui tahapan Orientasi, tahapan Pertukaran Penjajakan Afektif, tahapan Pertukaran Afektif dan tahapan Tahap pertukaran stabil. Apa saja faktor pendukung dan faktor penghambat Pembina Lapas dalam membina narapidana narkoba di lapas kelas IIA Banda Aceh.

Tujuan Penelitian ini untuk mengetahui komunikasi komunikasi antarpribadi antara petugas lapas dan narapidana melalui tahapan Orientasi, tahapan Pertukaran Penjajakan Afektif, tahapan Pertukaran Afektif dan tahapan Tahap pertukaran stabil. 


\section{METODOLOGI}

Penelitian ini menggunakan metode penelitian kualitatif. Sifat dari pendekatan kualitatif ini realitas bersifat ganda, rumit, dinamis, dan kebenaran realitas bersifat dinamis.(Mulyana, 2013:147).

Selain itu, penelitian kualitatif adalah proses penelitian dan pemahaman yang didasarkan pada metodologi yang menyelidiki suatu fenomena sosial dan masalah manusia. Pada pendekatan ini, peneliti membuat suatu gambaran kompleks, meneliti kata-kata, laporan terinci dari pandangan responden, dan melakukan studi pada situasi yang alami (Creswell, 1998:15)

Menurut Jane Richie (dalam (Moleong, 2010)) penelitian kualitatif adalah upaya untuk menyajikan dunia sosial, dan perspektifnya di dalam dunia, dari segi konsep,perilaku, persepsi, dan persoalan tentang manusia yang diteliti. Sehingga Dalam penelitian ini peneliti ingin mengetahui komunikasi antarpribadi petugas lapas dalam membina narapidana narkoba di lapas kelas IIA Banda Aceh dan ingin mengetahui faktor pendukung dan factor penghambat Pembina lapas dalam membina narapidana narkoba di Lapas tersebut. Teknik pengumpulan data adalah teknik yang digunakan peneliti untuk memperoleh data.

Dalam penelitian ini teknik yang digunakan untuk mengumpulkan data diantaranya: Observasi dan Wawancara dilakukan selama tiga bulan. Observasi merupakan kegiatan mengamati secara langsung, yang diobservasi adalah pelaksanaan pembinaan narapidana dan juga mengamati bagaimana proses pelaksanaan pembinaan tersebut. Dengan observasi secara langsung peneliti dapat memahami konteks data dalam berbagai situasi, maksudnya dapat memperoleh pandangan secara menyeluruh. Observasi yang dilakukan oleh peneliti dengan cara terjun langsung ke lapangan yaitu di Lapas Kelas IIA Banda Aceh.Wawancara adalah usaha untuk mengumpulkan informasi dengan mengajukan sejumlah pertanyaan secara langsung. Ciri utama dari wawancara adalah kontak langsung dengan tatap muka antara sipencari informasi dengan sumber informasi (Sutopo, 2006: 74).

Informan pada penelitian ini terdiri dari pembina lapas dan narapidana. Pembina lapas yaitu; Yosi Yulia menjabat sebagai kepala seksi administrasi keamaan dan ketertiban, Zailani manjabat Kepala Subseksi Sarana Kerja, Dimas jabatan sebagai Bimbingan Kemasyarakatan dan Keperawan, Andriangri menjabat kepala Kesatuan Penjagaan Laut dan Pantai (KPLP), dan narapidana berinisial MS, MN, HM, SM.

Analisis data dalam penelitian kualitatif dilakukan secara simultan sejak proses pengumpulan data, interpretasi data dan penulisan naratif. Pada saat pengumpulan data berlangsung dan selesai pengumpulan data dalam periode tertentu. Pada saat wawancara, peneliti sudah melakukan analisis terhadap jawaban yang bergantung pada situasi dan kondisi di lapangan.

Miles dan Huberman (dalam Sugiyono, 2012) mengemukakan bahwa aktivitas dalam analisis data kualitatif dilakukan secara interaktif dan berlangsung secara terus menerus sampai tuntas, sehingga datanya sudah jenuh. Adapun tahapan yang harus dilakukan dalam teknik analisis data adalah sebagai berikut: Reduksi Data, Display Data dan Kesimpulan

\section{HASIL DAN PEMBAHASAN}

Berdasarkan hasil wawancara yang peneliti lakukan di lingkungan Lapas Kelas IIA Banda Aceh terhadap petugas lapas dalam melakukan pembinaan kepada narapidana narkoba, mereka menggunakan komunikasi antarpribadi melalui pendekatan personal. Cara ini dilakukan sebagai bentuk kepedulian petugas pembina kepada warga binaan agar mereka lebih 
merasa dihargai sehingga kenyamanan dan rasa aman pun tumbuh dalam dirinya. Serta mewujudkan keakraban dan adanya saling keterbukaan informasi baik petugas lapas maupun warga binaan.

Warga binaan yang menjalani pembinaan di lapas kelas IIA Banda Aceh merasakan efek dari komunikasi antarpribadi melalui pendekatan personal tersebut. Pendekatan komunikasi antarpribadi menjadikan kualitas untuk hidup bagi para narapidana meningkat, merasa lebih produktif, sudah mulai membangun komunikasi dengan lingkungan sosial mereka. Dan untuk mengukur efektivitas komunikasi antarpribadi,dibutuhkan lima indikator yang dipaparkan oleh DeVito dalam (Liliweri,1997:13) yaitu keterbukaan (Openess), empati (Emphaty), dukungan (Supportiveness), rasa positif (Possitiveness), dan kesamaan (Equality).

\section{Keterbukaan (Openess)}

Untuk mewujudkan keterbukaan diri antara petugas lapas dengan warga binaan diharuskan saling terbuka antara satu sama lain,agar terciptanya kelancaran pembinaan yang dilakukan petugas lapas terhadap warga binaan. Pada tahap ini petugas menceritakan pengalaman pribadi mereka kepada warga binaan sebagai bentuk rasa keterbukaan diri mereka, seperti pernyataan Bapak Yossi yaitu: "Iya, terkadang kita menceritakannya,untuk saling memahami yang kita lakukan harus berbagi dalam hal yang positif-positif untuk dapat mereka ambil, begitu juga kami ada hal-hal yang baik kita ambil juga, karena belum tentu yang salah akan selalu salah pasti ada sisi baiknya juga." (wawancara: Yossi Yulia, S.H, petugas lapas, 6 maret 2019). "Cara kita merangkul mereka ya dengan cara mengetahui apa hobi dan kesukaan masingmasing" (wawancara: Yossi Yulia, S.H, petugas lapas, 6 maret 2019).

Menurut Bapak Yossi menceritakan pengalaman pribadi itu dapat dilakukan untuk saling berbagi kepada narapidana akan tetapi dalam hal positif. Karena dengan begitu dapat mempermudah proses pembinaan yang dilakukan petugas lapas kepada narapidana, ketika mereka terbuka satu sama lain program-program pembinaan pun berjalan dengan lancar. Pendapat yang sama juga disampaikan informan narapidana, seperti yang diungkapkan oleh HM yaitu: "Ya, karena saya menganggap mereka sebagai keluarga saya dimana tempat saya berbagi cerita, canda dan tawa serta saling bertukar pikiran dengan mereka meminta pendapat dan saran yang baik kepada mereka, saya sering menceritakan pengalaman pribadi saya karna disitu saya belajar untuk menjadi lebih baik lagi”. (wawancara: HM, 7 maret 2019).

Setelah melakukan observasi lapangan pada 20 Februari 2019 sesuai dengan pernyataan petugas lapas dan warga binaan narkoba. Dimana peneliti melihat keduanya saling bercerita pengalaman pribadi satu sama lain dan tidak ada rasa canggung diantara keduanya, sehingga membuat program pembinaan berjalan dengan baik.

\section{Empati (Emphaty)}

Pada tahap ini petugas Bapak Jaelani S.Sos, memberikan jawaban wawancara mengenai rasa empati antara petugas dan narapidana sebagai berikut: "Pada bulan November 2018 lalu ibu mertua dari salah satu warga binaan meninggal dunia. Karena masa tahanannya masih lama dan peraturan tidak mengizinkan yang bersangkutan untuk mendapat izin takziah maka kita adakan tahlilan dan mengundang tokoh agama."(wawancara : Jaelani S.Sos, Petugas Lapas 6 Maret 2019).

"Ada, seperti salah satu keluarga atau kerabat narapidana meniggal, para petugaslapasmelakukantahlilan dan diikuti oleh narapidana" (Wawancara: HM, Narapidana 6 Maret 2019).

"Setiap petugas dan narapidana meliliki rasa kekeluargaan, seperti saling 
mengucapkan duka cita ketika salah satu diantaramereka mengalami musibah,bahkan ada yang saling meminjamkan uang antara petugas lapas dan narapidana." (Wawancara: MN, Narapidana 7 Maret 2019).

Rasa empati yang terjadi antara petugas lapas dan narapidana di lapas kelas IIA Banda Aceh yaitu dalam bentuk saling memberikan belasungkawa kepada yang mengalami musibah. Selain itu juga rasa empati yang terjadi yaitu saling membantu antara satu samalain dengan meminjamkan uang atau mentraktir makanan oleh petugas lapas kepada narapidana.

Namun pada melakukan observasi pada tanggal 20 Februari 2019 peneliti tidak menemukan atau melihat kegiatan yang berupa tahlilan atau doa bersama yang berbentuk rasa empati antara petugas lapas dan narapidana. Dikarenakan pada saat observasi dilakukan tidak adanya musibah yang menimpa mereka. Tetapi sesuai pengakuan informan warga binaan kegiatan tersebut pernah dilakukan beberapa kali sebelumnya. Selain itu rasa empati yang diberikan petugas lapas kepada narapidana dalam bentuk lain berupa meminjamkan uang bagi narapidana yang keluarganya belum datang menjenguk.

\section{Dukungan (Supportiveness)}

Setiap pendapat atau ide serta gagasan yang disampaikan akan mendapatkan dukungan dari pihak-pihak yang berkomunikasi. Dukungan membantu seseorang untuk lebih bersemangat dalam melaksanakan aktivitas serta meraih tujuan yang diharapkan. Seperti wawancara petugas lapas Bapak Yossi:

"Lebih ke interaksi langsung dengan narapidana ketika ada apa-apa. Seperti kita kan sering berjalan di dalam lapas untuk kontrol narapidana terus kita berkomunikasi dengan mereka, kita tanya apa keluhannya, apa yang kurang, kita tampung keluh kesah mereka". (wawancara, Dhimas, petugas lapas, 6 maret 2019).
"Sangat baik mereka kepada petugas, dan kita pun harus menjaga sikap yang baik kepada mereka." (wawancara, Jaelani, S.Sos, 6 Maret 2019).

Salah satu contoh Supportiveness memberikan arahan dan dukungan kepada narapidana terhadap masalah yang menimpa mereka, kelanjutan kasus mereka dan dukungan-dukungan lainnya. Selain itu petugas lapas juga memberikan dukungan dengan cara mendengarkan keluh kesah para narapidana, apa saja kekurangan dan ketidaknyamanan para narapidana yang dirasakan. Salah satu petugas juga mengakui bahwa narapidana memberika respon yang baik dan sopan dalam setiap kegiatan yang diintruksikan oleh petugaslapas.

"Proses pembinaannya ramah, komunikasi yang digunakan ya komunikasi spontan, materi yang di sampaikan menyangkut dengan bimbingan-bimbingan, ada dari petugas dan ada juga yang didatangkan dari luar, ada beberapa kali dalam seminggu" (wawancara, M S, 7 Maret 2019)."

Salah satu narapidana juga mengakui bahwa para petugas memberikan arahan dengan ramah dan baik. Selain itu proses komunikasi yang terjadi juga secara spontan dan tidak formal. Ada juga petugas yang didatangkan dari luar beberapa kali dalam seminggu. Petugas yang ditugaskan dari luar juga menghangatkan suasana dengan saling bercanda dan menghibur narapidana pada kegiatan pembinaan.

Dalam Observasi yang dilakukan pada tanggal 20 Februari 2019, peneliti mengamati bahwa setiap petugas dan narapidana saling memberikan rasa dukungan satu sama lain baik dalam program pembinaan maupun dalam kegiatan sehari-hari. Hal itu diamati oleh peneliti pada saat petugas lapas memberikan intruksi kepada narapidana yang direspon dengan baik oleh warga binaan. 


\section{Rasa positif (Possitiveness)}

Apabila pembicaraan antara komunikator dan komunikan medapatkan tanggapan positif dari kedua belah pihak, maka percakapan selanjutnya akan lebih mudah dan lancar. Rasa positif menjadikan orang-orang yang berkomunikasi tidak berprasangka buruk atau curiga yang dapat menganggu jalinnya komunikasi.

"Kepercayaan yang dibangun ada ya cuma tidak sepenuhnya karena memang sudah prinsip masing-masing." (wawancara: Andriyas Dwi, 6 Maret 2019).

"Kalau belajar satu sama lain tetap, karena ada seminar-seminar, kitakan berbagi informasi, kadang-kadang kita ada informasi yang kita tidak tau, maka napi akan sampaikan, disitulah adanya saling berbagi." (wawancara: JaelaniS.Sos, 6 Maret 2019).

"Kalau ada informasi berita dari mereka, mereka selalu mau berbagi dengan kita. (wawancara: SN, 7 Maret 2019).

Possitiveness yang terjadi dalam Lapas Kelas IIA berupa bentuk kepercayaan yang diberikan oleh petugas kepada narapidana, namun masih di dalam pengawasan dan tidak melanggar aturan yang berlaku. Selain itu, saling berbagi informasi juga merupakan dampak positif dalam komunikasi antarpribadi yang terjadi dalam Lapas Kelas IIA.

\section{Kesamaan (Equality)}

Komunikasi akan lebih akrab dan jalinan pribadi akan menjadi semakin kuat apabila memiliki kesamaan tertentu antara komunikator dan komunikan dalam hal pandangan, sikap, kesamaan, ideologi, dan lain sebagainnya.

"Mengelola hubungan sosial dengan cara saling menyapa dalam setiap melakukan pembinaan dan menjaga silaturrahmi.(wawancara, Yossi Yua, S.H, petugas lapas, 6 maret 2019).

"Sikap petugas sangat baik, mereka sangat ramah dan santai terhadap narapidana sehingga kami warga binaan pun jadi nyaman dan bisa menjadi teman, dan kami pun jad imerasa dekat dengan petugas lapas". (wawancara, MN, 7 maret 2019).

Sifat Equality dalam komunikasi antarpribadi yang terjadi dalam Lapas Kelas IIA Banda Aceh yaitu dalam menjalin hubungan sehari-sehari antara narapidana dan petugas lapas. Narapidana mengaku petugas lapas menjalin hubungan sosial yang baik dengan para narapidana sehingga menimbulkan rasa nyaman dalam lingkungan Lapas Kelas IIA.

Dalam proses komunikasi terdapat faktor pendukung dan penghambat dalam berkomunikasi. Berdasarkan hasil wawancara peneliti terhadap Andriyas Dwi selaku Kepala KPLP mengatakan bahwa:

"Komunikasi berjalan baik jika pemenuhan kebutuhan hidup sesuai dengan yang diharapkan, maka dari itu dalam meningkatkan kinerja serta kesejahteraan dibutuhkan saling keterbukaan denga kan $n$ tugas masing- masing, serta adanya kebersamaan antara pembina dan warga binaan." (wawancara: Andriyas Dwi, 6 Maret 2019).

Komunikasi merupakan penunjang keberlangsungan hubungan antar sesama baik dalam suatu instansi maupun dalam kehidupan sehari-hari. Untuk mencapai tujuan tersebut faktor pendukung dalam berkomunikasi sangat diperlukan. Berdasarkan hasil wawancara peneliti terhadap bapak Yossi Yulia selaku Kasi ADM. KAMTIB mengatakan bahwa:

"Setelah menjalani pembinaan dalam proses rehabilitasi warga binaan akan mendapatkan hadiah, remisi, pembebasan bersyarat. Serta bantuan dari BNN merupakan faktor pendukung dalam bentuk fisik dan penunjang adanya peningkatan dari fasilitas lapas." (Wawancara: Yossi Yulia, S.H, petugas lapas, 6 Maret 2019).

Komunikasi aberjalan baik jika pemenuhan kebutuhan hidup atau fasilitas Lembaga pemasyarakatan sesuai dengan yang diharapkan. Maksudnya seseorang 
Pembina akan menjalin hubungan baik antara Pembina dan warga binaan/ pemakai narkoba apabila kebutuhan hidupnya terpenuhi baik dari segi psikologis, fisik, dan materi.

Sarana dan prasarana yang digunakan juga menjadi faktor pendukung dalam pelaksanaan program rehabilitasi Nasional di dalam Lembaga Pemasyarakatan mengacu kepada standar rehabilitasi sosial di Lembaga Pemasyarakatan yang ditetapkan oleh Kementrian Hukum dan HAM, dan standar Nasional Pelayanan ketergantungan Narkoba bagi Unit dan atau Lembaga Rehabilitasi Instansi Pemerintah yang ditetapkan oleh BNN yang disesuaikan dengan kondisi dan situasi Lapas (tabel 1). Berdasarkan hasil wawancara peneliti terhadap saudara MS selaku warga binaan di Lembaga Pemasyarakatan mengatakan bahwa:

"Menurut saya sarana dan prasarana yang disesuaikan dengan kondisi dan situasi di Lembaga Pemasyarakatan sudah memadai baik dari ruang administrasi, blok khusus warga binaan peserta rehabilitasi, poli klinik, ruang serba guna, tempat ibadah, dapur dan tempat olah raga." (Wawancara: MS, Narapidana 7 Maret 2019).

Tabel 1. Program Rehabilitasi Lembaga Pemasyarakatan

\begin{tabular}{lll}
\hline No & \multicolumn{1}{c}{ Program } & \multicolumn{1}{c}{ Jadwal } \\
\hline 1. & Senam dan Lari Pagi & Setiap Hari Sabtu \\
2. & Voly dan Bulutangkis & Setiap Sore \\
3. & Sholat Wajib Berjamaah & Setiap Hari \\
4. & Ceramah Agama (Pemater Dari Kemenag) & Setiap Hari Jumat \\
5. & Pengajian Al- Quran & Setiap Hari \\
6. & Pembinaan Pendidikan & Setiap Hari \\
7. & Pembinaan Konseling & Setiap Hari \\
8. & Pembinaan Keterampilan & Setiap Hari \\
\hline
\end{tabular}

Sumber: Data Penelitian, 2019.

Berdasarkan hasil wawancara peneliti terhadap saudara MN selaku warga binaan di Lembaga Pemasyarakatan mengatakan bahwa: "Bagi warga binaan yang beragama Islam setiap hari Senin pagi Masjid Miftahul Jannah di Lembaga Pemasyarakatan Kelas IIA Banda Aceh melaksanakan Pengajian oleh Tengku/Ustad dari Kementerian Agama Kota Banda Aceh, (Wawancara: MN, Narapidana, 7 Maret 2019).

Faktor pendukung yang biasa terjadi di Lembaga Pemasyarakatan Kelas IIA Banda Aceh ialah kerja sama di antara pegawai, relasi sosial dengan orang lain yang baik dapat memungkinkan untuk beraktifitas atau melakukan berbagai hal yang diinginkan. Bila hubungan antara warga binaan dan pegawai Lembaga
Pemasyarakatan berjalan dengan baik maka semua kegiatan yang diberikan pun akan berjalan dengan baik pula. Sehingga warga binaan sangat mendukung semua aktifitas yang dilakukan di Lembaga Pemasyarakatan. Namun apabila di antara sesama warga binaan dan pegawai tidak terjalin hubungan yang baik maka segala kegiatan yang dijalankan di Lembaga Pemasyarakatan pun tentunya tidak berjalan dengan baik.

Sebagian besar memberi tanggapan bahwa hubungan mereka dengan pegawai Lembaga Pemasyarakatan selama ini cukup baik. Hal ini dapat dilihat pula pada pemahaman mereka akan kondisi selama berada di Lembaga Pemasyarakatan maupun keterampilan- keterampilan yang diberikan, ternyata diterima dengan cukup 
baik. Hubungan yang baik didukung oleh sikap dan perilaku dari para warga binaan dalam menyesuaikan diri dengan lingkungan Lembaga Pemasyarakatan.

Suatu organisasi pimpinanlah yang bertanggung jawab akan pelaksanaan tugas organisasi, tapi tidak berarti harus mengambil alih semua tugas tersebut. Pimpinan dalam pelaksanaan tugas harus menunjuk orang lain dalam hal ini pegawai/anggota tersebut.

\section{Dukungan Pimpinan Lembaga}

Kepala Lembaga Pemasyarakatan harus melakukan sebuah perencanaan maupun pengawasan dan pemberian tugas dengan cara yang tepat dan benar kepada bawahan/pegawainya. Komunikasi Pimpinan kepada pegawai/ bawahan yang baik akan menghasilkan kinerja pegawai karena mereka merasa dihargai keberadaannya. Karena itu pimpinan harus mampu menciptakan suasana komunikasi yang kondusif dan mudah dimengerti oleh pegawai, selain itu atasan harus mampu menciptakan kreatifitas dalam melaksanakan kepemimpinannya, baik dalam kemajuan instansi ataupun produktifitas kerja pegawai.

Berdasarkan hasil wawancara dan pengamatan peneliti terhadap bapak Dhimas selaku, selaku staff Bimaswat Lapas Kelas IIA Banda Aceh, bahwa "Hubungan komunikasi antara pimpinan dengan pegawai di kantor Lembaga Pemasyarakatan Kelas IIA Banda Aceh sejauh ini masih berjalan dengan kondusif dan harmonis, dalam menciptakan komunikasi yang intensif maka kami di Lembaga Pemasyarakatan Kelas IIA Banda Aceh dalam melaksanakan tugas sesuai dengan tupoksi dan tanggung jawab masing- masing pegawai. Proses komunikasi yang kami ciptakan, baik dari pimpinan dan pegawai atau bawahan dan sebaliknya harus berdasarkan jenjang struktur yang telah ditetapkan."

\section{Loyalitas Pembina}

Loyalitas Pegawai menjadi faktor pendukung berlangsungnya keberhasilan atas tugas yang diberikan. Loyalitas berarti mengikuti dengan patuh peraturan atau sistem yang ada di Lembaga Pemasyarakatan, bertanggung jawab pada tugas yang telah diberikan, kemauan untuk bekerja sama dengan pegawai yang lain, dan hubungan antarpribadi yang baik terhadap pegawai lain dan juga terhadap atasannya.

\section{Dukungan Masyarakat}

Dukungan masyarakat juga merupakan faktor pendukung terhadap pembinaan di Lembaga Pemasyarakatan terkait stigma dan diskriminasi terhadap mereka dalam lingkungan masyarakat. Mereka yang sedang menjalani rehabilitasi sosial sudah bisa diberdayakan untuk menjadi role model bagi masyarakat khususnya generasi muda akan bahaya penyalahgunaan narkoba. Kemauan para pemakai narkoba mengakui dirinya sebagai orang yang telah pulih atau clean dari narkoba menjadi nilai positif bagi masyarakat, sekaligus menjadi pelajaran berharga bahwa secara fisik mereka tidak bisa dibedakan dengan orang yang sehat.

\section{Faktor Penghambat}

Faktor penghambat yang biasa terjadi di Lembaga Pemasyarakatan Kelas IIA Banda Aceh menurut para Pembina yaitu hambatan disebabkan karena perbedaan latar belakang psikologis, pengalaman, pendidikan, dan sumberdaya manusia yang ada di Lembaga Pemasyarakatan.

\section{Faktor psikologis}

Permasalahan yang menjadi kendalakendala dalam penerapan komunikasi antarpribadi di Lapas Kelas IIA Banda Aceh selalu ada. Seiring perkembangannya, para pembina senantiasa mengalami kendala-kendala dalam penerapan komunikasi antarpribadi kepada warga 
binaan/pemakai narkoba. Mereka para Warga binaan mengalami kesulitan mental akibat penyalahgunaan narkoba. Kualitas mental mereka mengalami gangguan seperti cepat emosi, merasa minder baik dalam lingkungan keluarga terlebih dalam lingkungan masyarakat. Permasalahan ini menjadikannya sering menyendiri.

Berdasarkan hasil wawancara dengan peneliti terhadap Bapak Jaelani, selaku Kasubsi Sarana Kerja mengatakan bahwa:

"Faktor penghambat yang sering dihadapi dalam proses komunikasi antarpribadi yaitu hambatan dari segi emosi, mudah tersinggung dan emosinya tidak stabil sedangkan dari segi perilaku yaitu warga binaan bandel/ lama kalau dipanggil saat melakukan pembinaan, pemalas, mudah terpengaruh, tidak percaya diri, agresif, cepat menyerah, tergesatergesa untuk mengambil keputusan/sulit untuk mengambil keputusan." (Wawancara, Jaelani, 6 Maret 2019)

Bagi Pembina lain, yang menjadi kendala adalah ketidak siapan bagi para pemakai atau warga binaan yang melakukan pembinaan dalam proses rehabilitasi sosial. Para warga binaan yang sebelumnya hanya terbiasa dengan kehidupannya yang senantiasa berusaha memenuhi kebutuhannya untuk memakai narkoba menjadi kendala dalam proses rehabilitasi. Hal ini terkait dengan aturan kedisiplinan yang diterapkan oleh para pembina. Berdasarkan hasil wawancara dengan peneliti terhadap bapak Dhimas mengatakan bahwa:

"Bagi saya pribadi, hambatan yang muncul bagi pembina saat ini dalam penerapan komunikasi ini adalah biasanya kedisiplinan warga binaan lama atau terlambat dipanggil untuk berkumpul pada saat mau melakukan pembinaan dan sebagai petugas harus lebih sabar dalam menghadapi warga binaan."

\section{Faktor pengalaman}

Kurangnya pengalaman menjadi hambatan pada saat aktivitas komunikasi berlangsung antara Pembina dan warga binaan. Berdasarkan hasil wawancara peneliti terhadap bapak Dwi Andriyas mengatakan bahwa:"Hambatan yang muncul pada tahap awal biasanya warga binaan masih malu-malu dan kurang terbuka kepada Pembina pada saat dibina dan status yang membedakan sebagai petugas dan warga binaan yang membuat pemakai narkoba/warga binaan merasa sungkan untuk menceritakan keluh kesahnya"

Latar Belakang Masyarakat Warga Binaan di Lapas Kelas IIA Banda Aceh juga menjadi faktor penghambat dalam penerapan komunikasi antarpribadi, indikator untuk mengetahui kurangnya penyesuaian diri juga dapat dilihat melalui sikap yang ditunjukkan oleh para warga binaan. Hasil penelitian menunjukkan bahwa masih terdapat warga binaan yang bersikap kurang baik terhadap pegawai Lembaga Pemasyarakatan. Hal ini dilihat dari relasi atau hubungan mereka dalam melakukan aktivitas sehari-hari termasuk kegiatan-kegiatan yang diprogramkan oleh pihak Lapas. Selain karena tidak mampu menyesuaikan diri, mereka juga tergolong warga binaan yang masih baru dan umurnya masih muda, sehingga pengendalian diri emosi masih sulit bagi mereka. Mereka menunjukkan sikap kurang senang dengan kegiatan-kegiatan yang diberikan oleh pegawai Lapas, bahkan sering melawan dengan cara tidak mau ikut kegiatan.

Aspek emosional yang baik akan sangat mendukung seseorang dalam bertindak dan mengambil suatu keputusan. Pengendalian emosi yang baik dapat dilihat dari sikap dan perilaku yang ditunjukkan, baik terhadap orang lain maupun dalam melakukan suatu aktifitas. Untuk mengetahui bagaimana emosi para warga binaan Lembaga Pemasyarakatan dapat ditunjukkan melalui sikap mereka dalam 
melakukan aktivitas sehari-hari dalam berelasi dengan pegawai maupun dengan sesama penghuni Lembaga Pemasyarakatan.

\section{Sumberdaya Manusia}

Sumber Daya Manusia (SDM) yang dibutuhkan dalam pelaksanaan pembinaan di Lapas Kelas IIA Banda Aceh mengacu kepada Standar Pelayanaan Rehabilitasi Sosial di Lembaga Pemasyarakatan yang ditetapkan oleh Kementrian Hukum dan HAM . Berdasarkan hasil wawancara peneliti terhadap bapak Yossi mengatakan bahwa: Hambatan yang dialami Lembaga Pemasyarakatan Kelas IIA Banda Aceh adalah Sumber daya manusia yang belum memadai juga menjadi kendala dalam proses rehabilitasi sosial. Padahal untuk melakukan rehabilitasi sosial dibutuhkan banyak disiplin ilmu untuk menangani masalah rehabilitasi sosial. Selama ini yang ikut terlibat untuk menangani masalah pembinaan sosial terbilang sedikit dibandingkan dengan angka manusia yang perlu direhabilitasi.

\section{Pembahasan}

Hasil penelitian akan dibagi kedalam tiga bagian yaitu bagaimana komunikasi antarpribadi petugas lapas dalam membina narapidana narkoba di Lapas Kelas IIA Banda Aceh dan apa saja faktor pendukung serta faktor penghambat Pembina Lapas dalam membina narapidana narkoba di Lapas Kelas IIA Banda Aceh. Interpretasi ini dilakukan berdasarkan hasil yang didapatkan pada analisis data yaitu Lapas Kelas IIA Banda Aceh adalah Unit Pelaksana Teknis (UPT) Pemasyarakatan dan bertanggung jawab pada Kantor Wilayah Kementerian Hukum dan Hak Asasi Manusia Provinsi Aceh melakukan pembinaan kepada narapidana narkoba.

Berdasarkan penelitian yang dilakukan oleh Siswati \& Aburrohim (2009), stressor tertinggi yang dialami narapidana adalah dari jumlah hukuman yang diterima. Narapidana dengan masa hukuman yang lebih lama cenderung memiliki tingkat stress yang tinggi. Perasaan tidak terima serta batasan bertemu dengan pihak keluarga merupakan masalah utama yang dialami oleh narapidana. Keadaan-keadaan seperti ini jika tidak segera ditangani akan menimbulkan tingkat stress yang tinggi dan berujung pada bunuh diri.

Pembinaan dapat diartikan sebagai rangkaian upaya pengendalian profesional terhadap semua unsur organisasi agar unsur-unsur yang disebut terakhir itu berfungsi sebagaimana mestinya sehingga rencana untuk mencapai tujuan dapat terlaksana secara efisien. Berdasarkan definisi ini maka dapat disimpulkan bahwa permbinaan adalah suatu proses, usaha, tindakan yang ditunjukan kepada narapidana secara bertahap agar menyadari kesalahan, memperbaiki dan meningkatkan kualitas narapidana tersebut.

Pembinaan narapidana yang dapat digambarkan oleh semua informan secara garis besar adalah bahwa pernyataan petugas dan narapidanaadanya keterbukaan pada saat pertama kali bertemu cukupbaik, karena menurut pengamatan penulis ini menjadi suatu awal dimana proses pertama dalam pembinaan bisa berjalan dengan baik. Dengansikap yang ditunjukanantarapetugas dan narapidana bisa dikatakan cukup membantu untuk lanjutan dari proses pembinaan, karena dengan sikap yang ramah dan saling menerima ini dapat menjadikan proses pembinaan lebih lancar.

Indikator keterbukaan dalam komunikasi antarpribadi diatas sesuai dengan tahapan pertama pada Teori Penetrasi Sosial oleh Irwin Altman dan Dalmas Taylor (1973) yaitu tahap orientasi. Dalam tahapan ini pembicaraan mengalir apa adanya dan biasanya orang cenderung bertindak sopan dan tidak mengkritik pada tahapanoreintasi. 
Sementara itu, Indikator supportiveness atau dukungan dalam komunikasi antarpribadi antara petugas lapas dan narapidana narkoba dinilai sudah baik. Jika kita lihat pelajaran yang diambil antara petugas dan narapidana menurut penulis cukup bijak, dimana semua informan menyatakan bahwa belajar dari kesalahan dan menerima pembelajaran itu bisa menjadikan seseorang lebih baik lagi kedepannya. Dalam proses pembinaan ini bisa diartikan sesuatu yang berjalan sebagaimana mestinya, dengan saling belajar maka petugas dan narapidana akan lebih memahami konsep diri dan belajar dari kesalahan.

Indikator dukungan atau supportiveness sesuai dengan tahapan pertukaran penjajakan afektif pada teori penetrasi sosial oleh Irwin Altman \& Dalmas Taylor (1973) yang mana tahap ini merupakan perluasan area publik dari diri yang sebelumnya private menjadi publik.

Emphaty dalam proses pembinaan antara petugas lapas dan narapidana juga dapat digambarkan dengan sesuatu yang dapat membantu jalannya proses pembinaan, dimana semua informan saling merasakan apa yang dirasakan satu sama lain.Begitu juga dengan indicator possitiveness dalam komunikasi antarpribadi yang mana kepercayaan yang ditunjukan oleh petugas dan warga binaan cukup senada, menurut peneliti mereka memberikan kepercayaan dimana dalam proses Pembinaan ini sangat diandalkan kepercayaan untuk menunjukkan sikap menerima dan membantu antara petugas dan narapidana itus endiri. Meskipun ada informan yang memberikan kepercayaan tidak sepenuhnya dikarenakan itu menjadi konsep dan prinsip diri sendiri.

Indikator Emphaty dan possitiveness dalam komunikasi antarpribadi di atas sesuai dengan tahapan pertukaran afektif pada teori penetrasi sosial. Yang pada tahap ini terdapat komitmen dan kenyaman. Tahap ini ditandakan dengan persahabatan yang dekat termasuk pola interaksi yang lebih santai dan terjadi secara spontan.

Selanjutnya, indikator equality pada komunikasi antarpribadi dalam kegiatan pembinaan pada Lapas Kelas IIA Banda Aceh terkait dengan mengelola hubungan sosial antara petugas dan narapidana. Dari semua informan menyatakan hal yang sama, mereka melakukan berbagai interaksi agar hubungan yang sudah terjalin dapat dijaga dengan baik. Adapula hubungan itu dijalin dari keluarga, ini menjadi suatu proses pembinaan yang berjalan sesuai sistem yang ada, karena tanpa hubungan yang di bangun maka akan menghambat jalannya pembinaan tersebut.

Indikator equality pada komunikasi antarpribadi sesuai dengan tahapan pertukaran stabil pada teori penetrasi sosial. Pada tahap ini informasi yang dibicarakan sudah sangat dalam dan menjadi inti dari pribadi masing-masing.

Bila kita lihat dalam teori penetrasi sosial yang dikembangkan oleh Irwin Altman dan Dalmas Taylor (1973) dimana proses pembinaan yang dilakukan petugas kepadanarapidanasudahnampaksesuaidenga nteori, yang pertama adanya orientasi yaitu perkenalan, yang kedua terjalinnya hubungan yang ramah, yang ketiga adanya suatu komitmen dan kenyamanan, yang terakhiradanyarespon yang baik. Ini menjadi suatu proses pembinaan yang maksimal apabila dijalankan sesuai dengan tahapan yang berlaku, oleh karena itu baik petugas Lapas dan narapidana harus saling memahami bagaimana komunikasi antarpribadi yang dibangun, jika itu sukses maka akan tercapainya suatu proses pembinaan yang baik pula.

Pada bagian ini, temuan sebainya dipisahkan dengan diskusi/pembahasan. Temuan atau hasil penelitian bukan bukan merupakan data mentah, melainkan data yang sudah diolah / dianalisis dengan metode tertentu. Pembahasan merupakan hasil interpretasi analisis data, jika perlu dikaikan dengan teori/konsep ilmiah 
relevan dalam tinjauan literatur. Temuan dan diskusi harus menjawab rumusan permasalahan dan memberikan dampak pengetahuan baru. Isi temuan dan diskusi dapat berupa interpretasi hasil pembahasan, tabel, gambar, diagram, grafik, sketsa, dan sebagainya.

\section{SIMPULAN}

Berdasarkan deskripsi dan pembahasan data peneliti maka dapat disimpulkan bahwa pelaksanaan pembinaan narapidana sudah berjalan dengan baik. Ini dapat dilihat dari hasil penelitian. Pelaksanaan pembinaan narapidana narkoba dengan pendekatan komunikasi antar pribadi di Lembaga Pemasyarakatan Kelas IIA Banda Aceh sudah memenuhi lima indkator dalam melakukan komunikasi antarpribadi yaitu keterbukaan, empati, sikap mendukung, positif dan kesamaan/kesetaraan. Faktor penghambat yang dihadapi dalam proses pembinaan adalah hambatan disebabkan karena perbedaan latar belakang psikologis, pengalaman, dan sumberdaya manusia yang ada di Lembaga Pemasyarakatan. Faktor pendukung yang dihadapi dalam proses pembinaan adalah Loyalitas pegawai dan kerja sama antara pegawai yang satu dengan yang lainnya, fasilitas atau sarana dan prasarana yang ada di Lembaga Pemasyarakatan, program yang dikembangkan di Lembaga Pemasyarakatan dan dukungan masyarakat menjadi faktor pendukung di Lembaga Pemasyarakatan Kelas IIA Banda Aceh.

\section{DAFTAR PUSTAKA}

Altman, I., \& Taylor, D. (1973). Social Penetration: The Development of Interpersonal Relationship. USA: Rinhart \& Winston Inc.

CNN Indonesia. (2018). Kronologi kerusuhan lapas di banda aceh berujung kebakaran. https://www.cnnindonesia.com/nasi onal/20180104192654 20266802/kronologi- kerusuhanlapas-di-banda-aceh-berujungkebakaran. Diakses pada 20 April 2018, Pukul 16.20 WIB.

Creswell, J. W. 1998. Qualitatif Inquiry and Research Design. Sage Publications, Inc: California

Gimawati. (2016). Komunikasi Antarpribadi Terhadap Pembinaan Pemakai Narkoba Di Lapas Wanita Kelas IIA Sunggumunasa Kecamatan Pattalassang Kabupaten Goa. Skripsi. Universitas Islam Negeri Alauddin Makassar.

Handayani, M. (2017). Pencegahan kasus kekerasan seksual pada anak melalui komunikasi antarpribadi orang tua dan anak. Visi, 12(1).

Kompas.Com. (2018). Kronologi kaburnya para napi dari lapas Banda

Aceh.https://nasional.kompas.com/r ead/2018/11/30/06254941/kronologi kaburnya-para-napi- dari-lapasbanda-aceh. Diakses pada 10 Desember 2018 pukul 10.00 WIB.

Kusuma, R. S. (2017). Komunikasi Antar Pribadi Sebagai Solusi Konflik Pada Hubungan Remaja dan Orang Tua Di Smk Batik 2 Surakarta. Warta LPM, 20(1), 49-54.

Londa, B. N. (2013). Efektivitas Komunikasi Antar Pribadi Dalam Meningkatkan Kesuksesan Sparkle Organizer. ACTA DIURNA KOMUNIKASI, 3(1).

Miles, M.B. \& Huberman, A.M. (1994). Qualitative data analysis: an expanded sourcebook, 2nd ed. Thousand Oaks: Sage Publications.

Moleong, L.J. (2010). Metodelogi Penelitian Kualitatif. Bandung: Remaja Rosda Karya.

Mulyana, Deddy. 2013. Metodologi Penelitian Kualitatif. Bandung: PT. Remaja Rosdakarya.

R. Wayne, Pace et al. (1979). Techniques Foe Effective Communication. 
Masschusets- Ontario: Addison Westley Publishing Company.

Rahardja, A. T. (2004). Hubungan Antara Komunikasi antar Pribadi Guru dan Motivasi Kerja Guru dengan Kinerja Guru SMUK BPK PENABUR Jakarta. Jurnal Pendidikan Penabur. III (3).[Online]. Tersedia: Www. Bpkpenabur. Or. Id/jurnal.[20 Oktober 2005].

Ramadanty, S. (2014). Penggunaan komunikasi fatis dalam pengelolaan hubungan di tempat kerja. Jurnal Ilmu Komunikasi, 5(1), 1-18.

Sri, W. I. (2017). Perilaku Komunikasi Interpersonal antara Pembina Lapas dan Warga Binaan Anak dalam Pembinaan di Lapas Kelas I
Makassar. Skripsi. Universitas Hasuddin Makassar.

Sugiyono (2012). Metode Penelitian Kuantitatif, Kualitatif, dan R\&D. Bandung: Alfabeta. Tanzeh, Ahmad (2009). Pengantar Metode Penelitian. Yogyakarta: Teras.

Umar, H. (2005). Metode Penelitian. Jakarta: Salemba Empat.

Warta Ekonomi. (2018). Polisi Temukan 183 Bungkus Ganja di LP Kelas IIA Banda Aceh https://www.wartaekonomi.co.id/rea d166613/news_post.php). Diakses pada 20 April 2018, Pukul 17.30 WIB

West, Richard, Lynn H. Turner. (2013). Pengantar Teori Komunikasi (Brian Marswendy.Terjemahan). Jakarta: Salemba Humanika. 